\title{
EFFECT OF SEVERE AIR-BLAST SHOT PEENING ON THE WEAR CHARACTERISTICS OF CP TITANIUM
}

\author{
VPLIV INTENZIVNEGA POVRŠINSKEGA KOVANJA S \\ PESKANJEM Z ZRAKOM NA OBRABNE LASTNOSTI CP-TITANA
}

\author{
Abdullah Cahit Karaoglanli \\ Department of Metallurgical and Materials Engineering, Bartin University, 74100 Bartin, Turkey \\ karaoglanli@bartin.edu.tr, cahitkaraoglanli@gmail.com \\ Prejem rokopisa - received: 2014-03-24; sprejem za objavo - accepted for publication: 2014-06-05
}

doi:10.17222/mit.2014.055

\begin{abstract}
In this study, air-blast shot peening was applied to analyze the wear characteristics of CP titanium (Grade II). The specimens were exposed to different plastic-deformation rates via different severe shot-peening conditions in order to determine the wear behaviour of CP titanium. A free-ball micro-abrasion test was performed on the specimens shot peened with different Almen intensities. Nanohardness measurements were also performed to investigate the work-hardened layer - the coarse-grainedstructure transition zone. Light microscopy and scanning electron microscopy (SEM) were used to analyze both the wear tracks and the severely deformed layer. As a result, the plastically deformed layer thickness reaches approximately $100 \mu \mathrm{m}$ beneath the surface. Moreover, the hardness and wear durability after severe shot peening is increased.
\end{abstract}

Keywords: air-blast shot peening, wear, nanoindentation, plastic deformation, ultra-fine-grain durability

V tej študiji je bilo uporabljeno peskanje z zrakom za študij lastnosti pri obrabi CP-titana (Grade II). Vzorci so bili izpostavljeni različnim stopnjam deformacije $v$ različnih razmerah peskanja, da bi ugotovili vedenje CP-titana pri obrabi. Izvršen je bil abrazijski preizkus z mikrokroglicami na vzorcih po peskanju z različno Almen-intenziteto. Izvršene so bile meritve nanotrdote za preiskavo utrjenega sloja in grobozrnate strukture prehodne cone. Za analizo sledov obrabe in močno deformiranih slojev sta bili uporabljeni svetlobna in vrstična elektronska mikroskopija (SEM). Debelina plastično deformiranega sloja doseže globino okrog $100 \mu \mathrm{m}$ pod površino. Trdota in odpornost proti obrabi se po močnem peskanju povečata.

Ključne besede: hladno kovanje površine s peskanjem z zrakom, obraba, nanoodtisek, plastična deformacija, odpornost ultra drobnih zrn

\section{INTRODUCTION}

Surface treatments are generally applied to metallic materials, particularly machine parts before service conditions to increase service life and efficiency. ${ }^{1}$ Mechanical properties such as wear, fatigue, fretting fatigue and corrosion are influenced by surface treatments. ${ }^{2,3}$ To analyze these mechanical and physical effects on the surface-treated materials, nanoindentation, scratch, hardness and thermal tests are performed. ${ }^{4-9}$ Surface treatments are investigated within the branch of mechanical and thermal surface treatments. Mechanical surface treatments cover a wide variety of processes and shot peening, laser peening, deep drawing, burnishing, sand blasting, brush cleaning are given as example processes. ${ }^{10,11}$ Nitriding, carburising, nitrocarburising, plasma nitriding and boriding processes are beneath the thermal-surface treatments. ${ }^{12}$

Shot peening has been widely used as a mechanical surface treatment to improve the fatigue resistance of critical machine parts. ${ }^{13}$ Also, the shot-peening effect on the oxidation, corrosion and fretting-fatigue properties of materials has been studied. ${ }^{13-15}$

Oxidation and the above mentioned properties are also important for coatings and other surface treatments. ${ }^{16,17}$
With respect to enhancing the mechanical properties without altering the chemical compositions of materials, severe plastic deformations attract a lot of attention. ${ }^{18}$ Severe plastic deformation, just as ECAP (equal-channel angular pressing), HPT (high-pressure torsion) or ARB (accumulative roll bonding) is performed to increase mechanical properties by decreasing the grain size of the whole bulk materials. ${ }^{18,19}$ Nevertheless, these methods are applied restrictedly due to the high-pressure requirements. Shot peening may be more influential if performed as a severe plastic deformation. ${ }^{19}$ It applies a high plastic deformation only to the material surfaces made of a wide variety of materials due to the easiness of the application. ${ }^{13,20}$ By raising the conditions of the conventional shot peening, severe shot peening which applies a very high plastic deformation to a material surface was conceived. ${ }^{20}$ In recent years, studies depicted that severe shot peening made positive contributions to the increased wear characteristics, creating fine-grained-surface bulk materials. ${ }^{21}$ Severe shot peening is applied in the ways of high-energy shot peening, ultrasonic shot peening, etc. ${ }^{22-24}$ Most of the severe-plastic-deformation studies show a highly deformed layer with ultra-fine grains that has superior mechanical properties in comparison with the interior parts. ${ }^{25}$ From this point of view, obtaining a highly deformed surface with better properties is a way of improving the wear properties of metallic mate- 
rials. ${ }^{26-28}$ Several techniques are used for determining the wear behaviour of materials..$^{29}$ Micro-abrasion is one of these test techniques due to its simplicity with respect to the abrasive-wear behaviour of materials. ${ }^{30}$

In this study, attention is focused on the mechanical properties and the wear characteristics of the bulk $\mathrm{CP}$ titanium materials with severely deformed surfaces. The specimens are subjected to a free-ball micro-abrasion test subsequent to a severe shot-peening process. The distinction between the severe shot-peened and as-received titanium specimens are performed via mechanical and physical investigations.

\section{EXPERIMENTAL STUDIES}

Commercially pure titanium (Grade II) material with the dimensions of $20 \mathrm{~mm} \times 20 \mathrm{~mm} \times 8 \mathrm{~mm}$ was machined and a normalizing heat treatment was performed to release the machining and manufacturing effects. The surfaces of the specimens were ground with 200, 400, 800 and 1200 grade emery papers and then mechanically polished with $6 \mu \mathrm{m}$ and $1 \mu \mathrm{m}$ pastes. The specimens were subjected to the air-blast severe shot peening with different Almen intensities (Table 1). In addition, the air pressures were (750, 800 and 870$) \mathrm{kPa}$ for $31 \mathrm{~A}, 35 \mathrm{~A}$ and 9C, respectively. The Almen intensities were selected due to the high-plastic-deformation exposure. ${ }^{20}$ The intensities were $31 \mathrm{~A}, 35 \mathrm{~A}$ and $9 \mathrm{C}$. The $\mathrm{C}$ Almen strip is used as the highest plastic deformation in comparison to the $\mathrm{A}$ and $\mathrm{N}$ strips. ${ }^{31}$

Table 1: Severe-shot-peening conditions for CP-titanium (Grade II) specimens

Tabela 1: Razmere pri močnem peskanju vzorca CP-titan (Grade II)

\begin{tabular}{|c|c|c|c|c|}
\hline $\begin{array}{c}\text { Specimen } \\
\text { No. }\end{array}$ & $\begin{array}{c}\text { Almen } \\
\text { intensity }\end{array}$ & Shot type & Shot size & $\begin{array}{c}\text { Coverage } \\
(\%)\end{array}$ \\
\hline 1 & $31 \mathrm{~A}$ & SAE-J2175 & S230 & 200 \\
\hline 2 & $35 \mathrm{~A}$ & SAE-J2175 & S230 & 200 \\
\hline 3 & $9 \mathrm{C}$ & SAE-J2175 & S230 & 200 \\
\hline
\end{tabular}

The specimens were etched with a $3 \%$ Nital solution following the severe shot-peening process. Afterwards light and SEM (Vega Tescan) microstructure images were obtained on the cross-sections and the peened surfaces. A Schimadzu DUH-W201S ultra-micro-hardness tester was used to determine the hardness alteration from the surface to the interior. The experimental load applied was $50 \mathrm{mN}$ and the duration was $10 \mathrm{~s}$.

The fixed-ball micro-abrasion test method was used for determining the wear performance of the shot-peened surfaces with different Almen intensities. The diameter, the material and the hardness of the ball were $25.4 \mathrm{~mm}$, AISI 52100 steel and $65 \mathrm{Rc}$, respectively. The wear volume was calculated using Equation (1): ${ }^{32}$

$$
V \approx \frac{\pi b^{4}}{64 R} \text { for } b<<R
$$

where $V$ is the volume of the material removed by wear, $b$ is the diameter of the wear crater, and $R$ is the radius of the ball.

The fixed-ball micro-abrasion tests were performed on the peened surfaces of the CP-titanium (Grade II) specimens for $2 \mathrm{~min}$, at $120 \mathrm{r} / \mathrm{min}$, under the normal loads of $(0.5,1$ and 1.5$) \mathrm{N}$ to determine the wear-volume loss on the peened-specimen surfaces. 800-mesh SiC particles were used as the abrasive and distilled water including $25 \% \mathrm{SiC}$ particles was used as the abrasive solution.

\section{RESULTS AND DISCUSSION}

The specimens peened with the 31A, 35A and 9C Almen intensities are shown in Figure 1. The images show the cross-sections of the peened specimens. A severe plastic deformation with a severe shot-peening
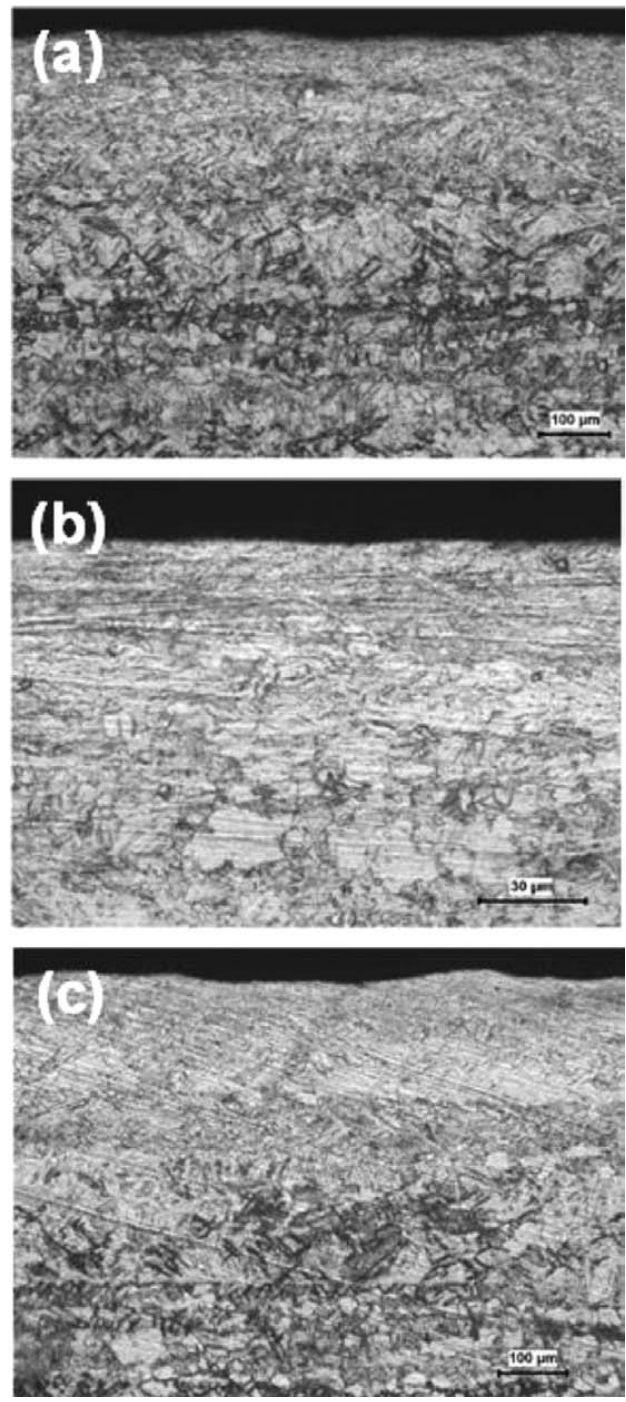

Figure 1: Light-microscope images of severely shot-peened titanium specimens peened with: a) $31 \mathrm{~A}$, b) $35 \mathrm{~A}$, c) $9 \mathrm{C}$ Almen intensities

Slika 1: Mikrostruktura močno peskanega vzorca iz titana $\mathrm{z}$ različno Almen-intenziteto: a) $31 \mathrm{~A}$, b) $35 \mathrm{~A}$, c) $9 \mathrm{C}$ 
exposure just below the surface is observed. Approximately $100 \mu \mathrm{m}$ beneath the surface, grain boundaries become dense and lose their homogeneity and visibility. With the increasing Almen intensity, especially at the intensity of 9C, a very dense, severely deformed surface can be noticed; it is separated from the interior structure because fine grains appear due to a high plastic deformation. Also, shot tracks and waves on the surface peened with $9 \mathrm{C}$ are denser compared with $31 \mathrm{~A}$ and $35 \mathrm{~A}$. In the literature the reported surface roughness also increases with the increasing plastic deformation. ${ }^{20}$

The severely deformed structure of the surface was investigated using a SEM analysis (Figure 2). In line with the studies made before, the images of the spe-
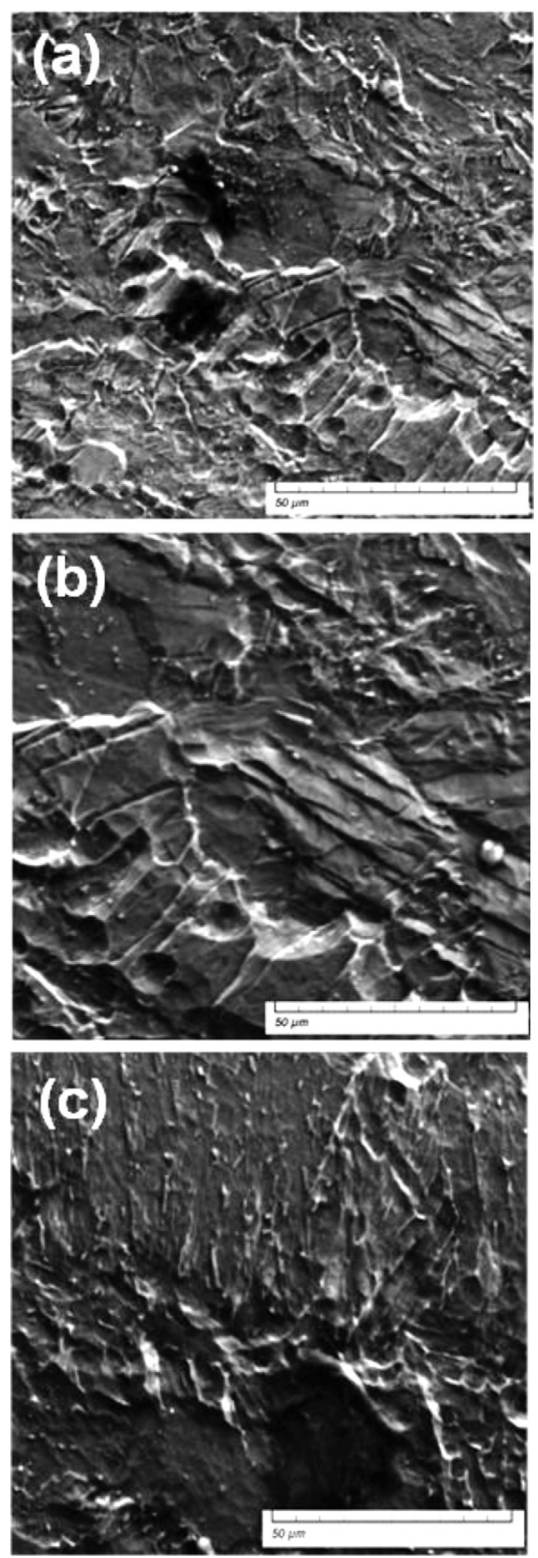

Figure 2: SEM images of severely shot-peened titanium specimens peened with: a) $31 \mathrm{~A}$, b) $35 \mathrm{~A}$, c) $9 \mathrm{C}$ Almen intensities

Slika 2: SEM-posnetki močno peskanega vzorca iz titana $\mathrm{z}$ različno Almen-intenziteto: a) 31A, b) $35 \mathrm{~A}$, c) $9 \mathrm{C}$

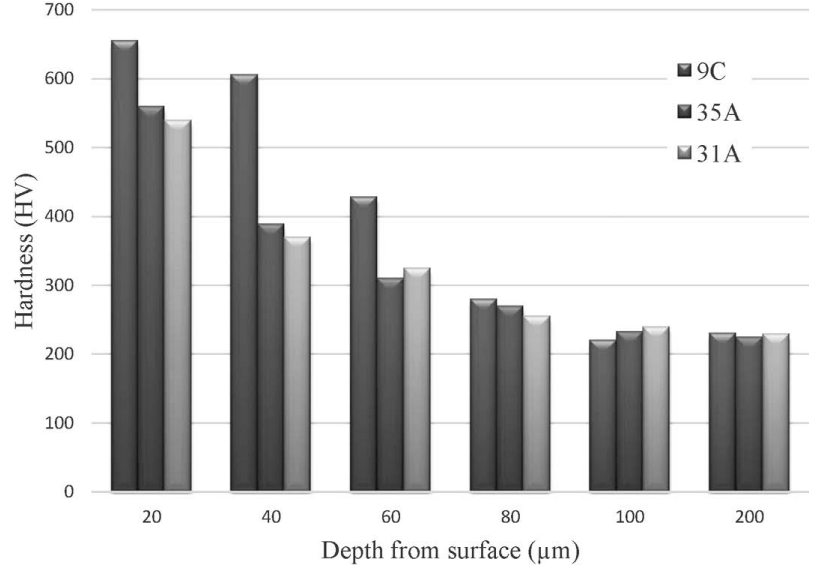

Figure 3: Hardness variation versus depth according to the Almen intensities

Slika 3: Spreminjanje trdote z globino glede na različno Almen-intenziteto

cimens peened with $31 \mathrm{~A}, 35 \mathrm{~A}$ and $9 \mathrm{C}$ show that a high plastic deformation ruined the homogenous microstructure and created quite a dense and heterogenous ultra-fine-grained structure. ${ }^{22,33-35}$ Although the magnifications are high, the grain boundaries cannot be seen. Due to a dislocation-density increase and piling up around the grains, the boundaries are invisible just like reported in ${ }^{36,37}$.

Nanohardness measurements were performed to determine the effect of the plastic deformation on the surface and the effect release to the interior. Figure 3 depicts the hardness variation from the surface to the bulk interior. As seen on the figure, after approximately $150 \mu \mathrm{m}$ a large part of the plastic-deformation impact was released, being very similar to the ones presented $i^{21,38}$. The hardness increase is the highest on the surfaces of the specimens. Nevertheless, for the specimen peened with the 9C Almen intensity, the hardness decrease does not occur as abruptly as in the cases of $31 \mathrm{~A}$ and $35 \mathrm{~A}$. As seen from Figure 1, an ultra-finegrain, highly deformed layer provides a higher and more stabilized hardness down to $50 \mu \mathrm{m}$.

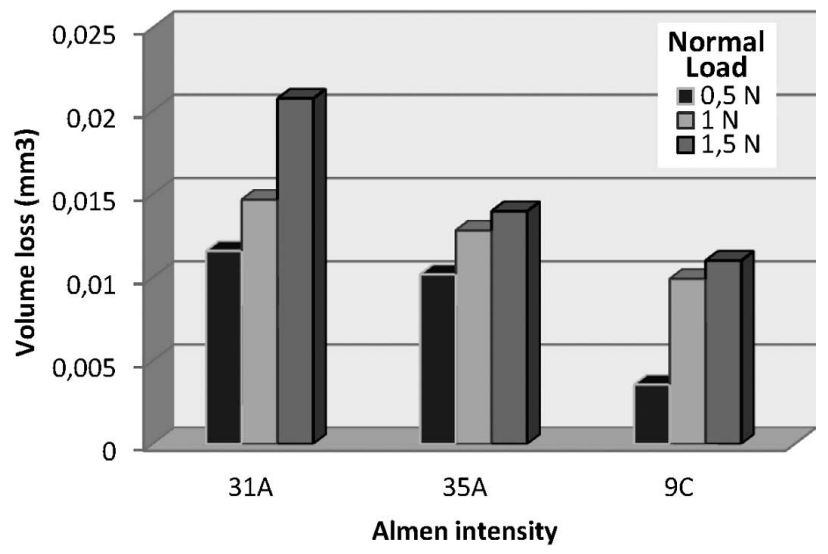

Figure 4: Volume loss versus Almen intensity for the normal load Slika 4: Izguba volumna v odvisnosti od Almen-intenzitete pri normalni obremenitvi 
The volume loss is evaluated on the basis of the crater dimensions from the light and SEM images. The mathematical approach taken from the literature was used in this study. ${ }^{21}$ The volume loss decreases with the increasing Almen intensity. The Almen intensity causes an exposure to a severe plastic deformation, increasing the hardness of the contact surfaces of the materials. The hardness increase induces a reduction in the wear-volume loss.

Figure 4 shows the graphs indicating the volume loss of the specimens, subjected to the wear process using the 800 -mesh $\mathrm{SiC}$ abrasives under the $(0.5,1$ and 1.5$) \mathrm{N}$ loads and shot peened at different Almen intensities. As seen in Figure 4, the volume loss of the specimens increased in parallel with the increasing load. This is due to the fact that the force applied on the particles, stuck between the subsurface and the ball, increases resulting in a higher shear force with a deeper plunge of the abrasive particles into the specimen.

The lowest volume losses are observed on the specimen shot peened at the 9C Almen intensity, followed by the specimens shot-peened with the $35 \mathrm{~A}$ and $31 \mathrm{~A}$ Almen intensities, respectively. This can be primarily attributed to the surface hardness of the specimens. It would be appropriate to correlate the surface hardness of a specimen with the plastic deformation occurring on the surface area of the specimen depending on the increasing Almen intensity, since the stresses generated on the surface result in an increased dislocation density, hence, an increased hardness in this area of the specimen. Additionally, the density of the compressive stresses generated in this area varies depending on the Almen intensity and has a positive effect on the wear resistance.

Figure 5 shows a SEM image of a crater formed as a result of the micro-abrasion wear test made on a specimen that was shot-peened at the 9C Almen intensity. The wear tracks, obtained as a result of the tests carried out in compliance with the ASTM G77 standard using different Almen values, exhibited a circular geometry as expected.

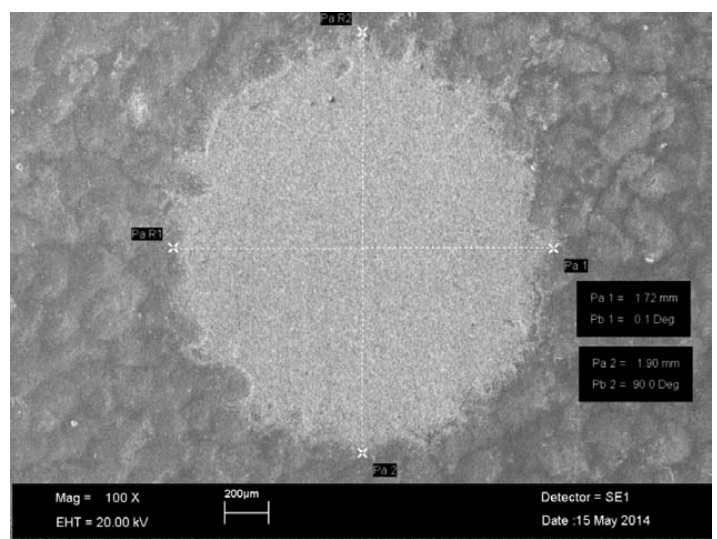

Figure 5: SEM image of a wear crater obtained on the titanium alloy shot peened with the 9C Almen intensity

Slika 5: SEM-posnetek kraterja na titanovi zlitini, peskani z 9C Almen-intenziteto
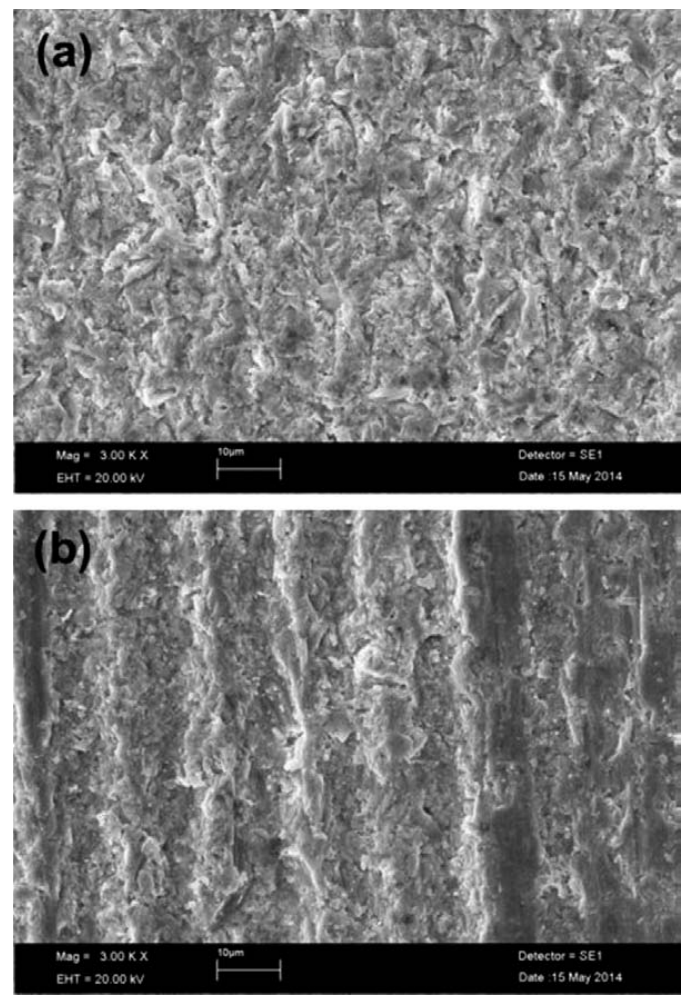

Figure 6: SEM images of the worn surfaces obtained with the 31A Almen intensity at the normal loads of: a) $0.5 \mathrm{~N}$ and b) $1.5 \mathrm{~N}$

Slika 6: SEM-posnetka obrabljene površine, obdelane z Almen-intenziteto 31 A pri obtežbi: a) $0,5 \mathrm{~N}$ in b) $1,5 \mathrm{~N}$

Figures 6a and $6 \mathbf{b}$ show the wear-surface images of the specimens subjected to the micro-scale abrasion process under the loads of $0.5 \mathrm{~N}$ and $1.5 \mathrm{~N}$ and shot-peened at the 31A Almen intensity. A three-body wear-abrasion mechanism was encountered on the specimens that were subjected to the wear process under $0.5 \mathrm{~N}$. This is due to the rolling abrasion of the abrasive particles on the surface. A two-body abrasion-wear mechanism, thereby, a groove formation was observed on the specimens, subjected to the wear process under $1.5 \mathrm{~N}$. This is a consequence of the plunging of the abrasive $\mathrm{SiC}$ particles into the ball surface with the increasing load, which results in a cut-off titanium alloy.

The wear-surface images of the specimens shot peened at the $35 \mathrm{~A}$ Almen intensity under the $0.5 \mathrm{~N}$ and $1.5 \mathrm{~N}$ loads are given in Figures $7 \mathbf{a}$ and $\mathbf{7 b}$. Here, the wear mechanisms occurring at the $31 \mathrm{~A}$ Almen intensity are observed as well; however, the groove depths, obtained under the load of $1.5 \mathrm{~N}$, happened to be lower due to a higher material hardness.

The wear-surface images of the specimens shot peened at the 9C Almen intensity are shown in Figure 8. The wear mechanism obtained under the $1.5 \mathrm{~N}$ load differs from that of the other two specimens. The plunging of the abrasive particles into the material surface was obstructed due to an increased surface hardness and a three-body abrasion mechanism was observed due to the rolling of these particles. 

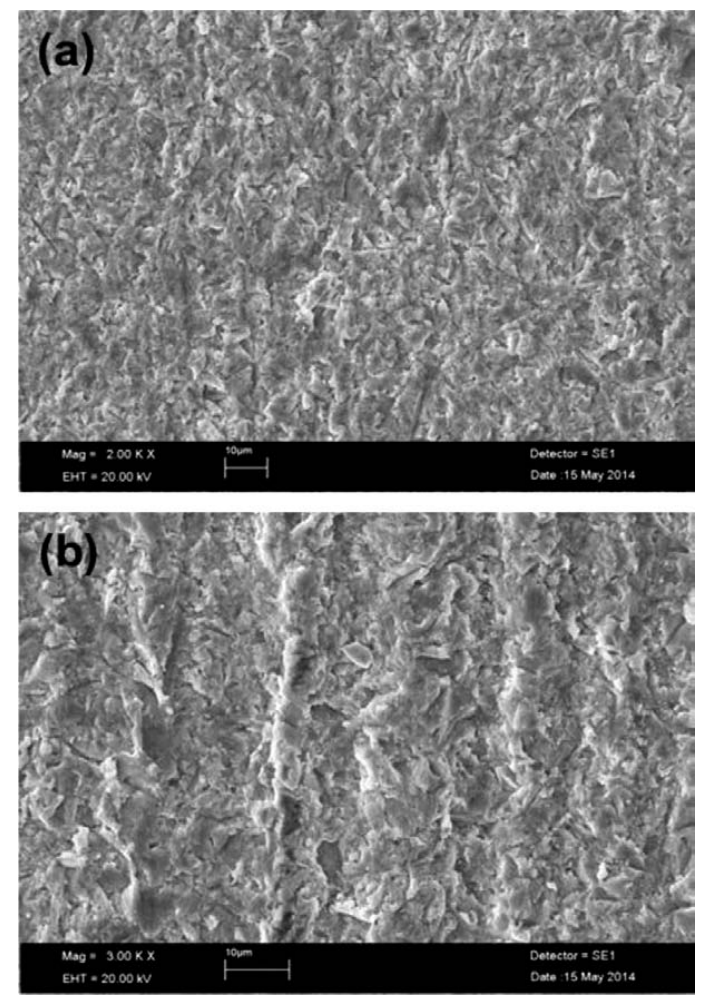

Figure 7: SEM images of the worn surfaces obtained with the 35A Almen intensity at the normal loads of: a) $0.5 \mathrm{~N}$ and b) $1.5 \mathrm{~N}$ Slika 7: SEM-posnetka obrabljene površine, obdelane z Almen-intenziteto 35A pri obtežbi: a) $0,5 \mathrm{~N}$ in b) $1,5 \mathrm{~N}$

\section{CONCLUSIONS}

In this study, commercially pure titanium (Grade II) specimens were subjected to severe air-blast shot peening with different Almen intensities. Different Almen intensities exposed the specimen surfaces to different plastic-deformation rates. Severe plastic-deformation rates caused a microstructural and mechanical behaviour alteration. With the increasing Almen intensity a finer and deeper grain structure occurred and this structure become more complex. However, according to the SEM images, although the magnifications were so high, the grain boundaries cannot be seen and the structure has a very dense layer and a plastically deformed surface. The hardness variation is also compatible with the optical and SEM images. With the decreasing Almen intensity the hardness was reduced and after approximately $100 \mu \mathrm{m}$ a large part of the plastic deformation was released. The wear-volume loss was reduced with the increasing Almen intensity. The highest wear resistance was obtained with the specimens shot peened at the $9 \mathrm{C}$ Almen intensity, followed by the $35 \mathrm{~A}$ and $31 \mathrm{~A}$ Almen intensities. On the specimens shot peened at the $9 \mathrm{C}$ Almen intensity a three-body abrasion-wear mechanism was observed at all normal loads. However, on the specimens shot peened at the $35 \mathrm{~A}$ and $31 \mathrm{~A}$ Almen intensities, three-body abrasion was observed at the low load
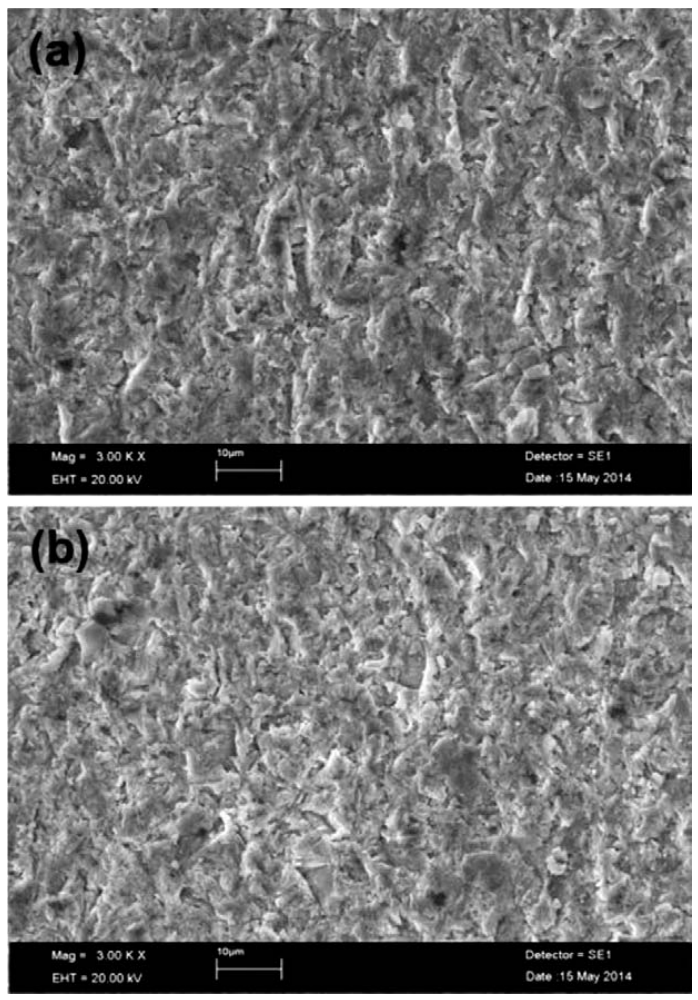

Figure 8: SEM images of the worn surfaces obtained with the $9 \mathrm{C}$ Almen intensity at the normal loads of: a) $0.5 \mathrm{~N}$ and b) $1.5 \mathrm{~N}$

Slika 8: SEM-posnetka obrabljene površine, obdelane z Almen-intenziteto 9C pri obtežbi: a) $0,5 \mathrm{~N}$ in b) $1,5 \mathrm{~N}$

$(0.5 \mathrm{~N})$ and two-body abrasion was observed at the high load $(1.5 \mathrm{~N})$. These results show that the Almen intensity and, thereby, the surface hardness are the key parameters for the control of the wear behaviour of a Ti alloy.

\section{Acknowledgments}

The author gratefully acknowledges the Turkish Air Force Air Supply and Maintenance Command for the shot-peening applications.

\section{REFERENCES}

${ }^{1}$ K. Z. Shepelyakovskiil, Bulk-surface hardening as a method for increasing strength, reliability, and service life of machine parts, Metal Science and Heat Treatment, 37 (1995) 11, 433-440, doi: 10.1007/BF01154216

${ }^{2}$ G. Q. Wu, Z. Li, W. Sha, H. H. Li, L. J. Huang, Effect of fretting on fatigue performance of Ti-1023 titanium alloy, Wear, 309 (2014) 1-2, 74-81, doi:10.1016/j.wear.2013.10.010

${ }^{3}$ W. Brostow, K. Czechowski, W. Polowski, P. Rusek, D. Toboła, I. Wronska, Slide diamond burnishing of tool steels with adhesive coatings and diffusion layers, Materials Research Innovations, 17 (2013) 4, 269-277, doi:10.1179/1433075X12Y.0000000060

${ }^{4}$ W. M. Ke, F. C. Zhang, Z. N. Yang, M. Zhang, Micro-characterization of macro-sliding wear for steel, Materials Characterization, 82 (2013), 120-129, doi:10.1016/j.matchar.2013.05.009

${ }^{5}$ A. Khellouki, J. Rech, H. Zahouani, Micro-scale investigation on belt finishing cutting mechanisms by scratch tests, Wear, 308 (2013), 17-28, doi:10.1016/j.wear.2013.09.016 
${ }^{6}$ B. D. Beakea, T. W. Liskiewicz, Comparison of nano-fretting and nano-scratch tests on biomedical materials, Tribology International, 63 (2013), 123-131, doi:10.1016/j.triboint.2012.08.007

L. Jiangliang, X. Dangsheng, W. Hongyan, H. Zhongjia, D. Jihui, T. Rajnesh, Tribological Properties of Laser Surface Texturing and Molybdenizing Duplex-Treated Ni-Base Alloy, Tribology Transactions, 53 (2010), 195-202, doi:10.1080/10402000903097478

${ }^{8}$ A. C. Karaoglanli, G. Erdogan, A. Turk, I. Ozdemir, F. Ustel, Study of the microstructural and oxidation behavior of YSZ and YSZ/ A12O3 TBCs with HVOF bond coatings, Mater. Tehnol., 46 (2012) 5, 439-444

${ }^{9}$ C. Edoardo, G. Luca, P. Barbara, Modelling of the transient thermal field in laser surface treatment test, The International Journal of Advanced Manufacturing Technology, 40 (2009), 307-315, doi: 10.1007/s00170-007-1350-z

${ }^{10}$ A. Igor, K. N. Ravi, S. Yuji, W. Lothar, O. R. Robert, On the effect of deep-rolling and laser-peening on the stress-controlled low- and high-cycle fatigue behavior of $\mathrm{Ti}-6 \mathrm{Al}-4 \mathrm{~V}$ at elevated temperatures up to $550{ }^{\circ} \mathrm{C}$, International Journal of Fatigue, 44 (2012), 292-302, doi:10.1016/j.ijfatigue.2012.03.008

${ }^{11}$ S. Anand Kumar, R. Sundar, S. Ganesh Sundara Raman, H. Kumar, R. Gnanamoorthy, R. Kaul, K. Ranganathan, S. M. Oak, L. M. Kukreja, Fretting Wear Behavior of Laser Peened Ti-6Al-4V, Tribology Transactions, 55 (2012), 615-623, doi:10.1080/10402004.2012. 686087

${ }^{12}$ B. Edenhofer, W. Grafen, J. Müller-Ziller, Plasma-carburising a surface heat treatment process for the new century, Surface and Coatings Technology, 142-144 (2001), 225-234, doi:10.1016/ S0257-8972(01)01136-7

${ }^{13}$ M. A. S. Torres, H. J. C. Voorwald, An evaluation of shot peening, residual stress and stress relaxation on the fatigue life of AISI 4340 steel, International Journal of Fatigue, 24 (2002), 877-886, doi:10.1016/S0142-1123(01)00205-5

${ }^{14}$ V. Azar, B. Hashemi, Y. M. Rezaee, The effect of shot peening on fatigue and corrosion behavior of 316L stainless steel in Ringer's solution, Surface and Coatings Technology, 204 (2010), 3546-3551, doi:10.1016/j.surfcoat.2010.04.015

${ }^{15}$ X. H. Zhang, D. X. Liu, H. B. Tan, X. F. Wang, Effect of TiN/Ti composite coating and shot peening on fretting fatigue behavior of TC17 alloy at $350{ }^{\circ} \mathrm{C}$, Surface and Coatings Technology, 203 (2009), 2315-2321, doi:10.1016/j.surfcoat.2009.02.058

${ }^{16}$ A. C. Karaoglanli, E. Altuncu, I. Ozdemir, A. Turk, F. Ustel, Structure and durability evaluation of YSZ $+\mathrm{Al} 2 \mathrm{O} 3$ composite TBCs with APS and HVOF bond coats under thermal cycling conditions, Surface and Coatings Technology, 205 (2011) 2, 369-373, doi:10.1016/j.surfcoat.2011.04.081

${ }^{17}$ A. C. Karaoglanli, H. Dikici, Y. Kucuk, Effects of Heat Treatment on Adhesion Strength of Thermal Barrier Coating Systems, Engineering Failure Analysis, 32 (2013), 16-22, doi:10.1016/j.engfailanal.2013. 02.029

${ }^{18}$ K. Kyungjin, Y. Jonghun, Evolution of the microstructure and mechanical properties of AZ61 alloy processed by half channel angular extrusion (HCAE), a novel severe plastic deformation process, Materials Science and Engineering A, 578 (2013), 160-166, doi:10.1016/j.msea.2013.04.073

${ }^{19}$ E. Kaveh, I. Kazutaka, K. Takanobu, H. Zenji, Equal-Channel Angular Pressing and High-Pressure Torsion of Pure Copper: Evolution of Electrical Conductivity and Hardness with Strain, Materials Transactions, 53 (2012) 1, 123-127, doi:10.2320/matertrans.MD201109

${ }^{20}$ O. Unal, R. Varol, Almen intensity effect on microstructure and mechanical properties of low carbon steel subjected to severe shot peening, Applied Surface Science, 290 (2014), 40-47, doi:10.1016/ j.apsusc.2013.10.184

${ }^{21}$ O. Unal, R. Varol, A. Erdogan, M. S. Gok, Wear behaviour of low carbon steel after severe shot peening, Materials Research Innovations, 17 (2013), 519-523, doi:10.1179/1433075X13Y.0000000106
${ }^{22}$ S. Bagherifard, P. I. Fernández, R. Ghelichi, M. Guagliano, Fatigue properties of nanocrystallized surfaces obtained by high energy shot peening, Procedia Engineering, 2 (2010), 1683-1690, doi:10.1016/ j.proeng.2010.03.181

${ }^{23}$ Y. K. Gao, Improvement of fatigue property in 7050-T7451 aluminum alloy by laser peening and shot peening, Materials Science and Engineering A, 528 (2011), 3823-3828, doi:10.1016/j.msea.2011. 01.077

${ }^{24}$ T. Chaise, J. Li, D. Nélias, R. Kubler, S. Taheri, G. Douchet, V. Robin, P. Gilles, Modelling of multiple impacts for the prediction of distortions and residual stresses induced by ultrasonic shot peening (USP), Journal of Materials Processing Technology, 212 (2012), 2080-2090, doi:10.1016/j.jmatprotec.2012.05.005

${ }^{25}$ N. A. Prakash, R. Gnanamoorthy, M. Kamaraj, Surface nanocrystallization of aluminium alloy by controlled ball impact technique, Surface and Coatings Technology, 210 (2012), 78-89, doi:10.1016/j.surfcoat.2012.08.069

${ }^{26}$ K. S. Anand, R. S. Ganesh Sundara, T. S. N. Sankara Narayanan, R. Gnanamoorthy, Fretting wear behaviour of surface mechanical attrition treated alloy 718, Surface and Coatings Technology, 206 (2012), 4425-4432, doi:10.1016/j.surfcoat.2012.04.085

${ }^{27}$ T. Fu, Z. F. Zhou, Y. M. Zhou, X. D. Zhu, Q. F. Zeng, C. P. Wang, K. Y. Li, J. Lu, Mechanical properties of DLC coating sputter deposited on surface nanocrystallized 304 stainless steel, Surface and Coatings Technology, 207 (2012), 555-564, doi:10.1016/j.surfcoat.2012. 07.076

${ }^{28}$ M. Mubarak Ali, S. Ganesh Sundara Raman, S. D. Pathak, R. Gnanamoorthy, Influence of plasma nitriding on fretting wear behaviour of Ti-6Al-4V, Tribology International, 43 (2010), 152-160, doi:10.1016/j.triboint.2009.05.020

${ }^{29}$ H. Caliskan, A. Erdogan, P. Panjan, M. S. Gök, A. C. Karaoglanli, Micro-abrasion wear testing of multilayer nanocomposite TiAlSiN/ TiSiN/TiAlN hard coatings deposited on the AISI H11 steel, Mater. Tehnol., 47 (2013) 5, 563-568

${ }^{30}$ A. C. Karaoglanli, H. Caliskan, M. Gok, A. Erdogan, A. Turk, A comparative study of the microabrasion wear behavior of CoNiCrAlY coatings fabricated by APS, HVOF and CGDS techniques, Tribology Transactions, 57 (2014) 1, 11-17, doi:10.1080/ 10402004.2013.820372

${ }^{31}$ S. Bagherifard, M. Guagliano, Influence of mesh parameters on FE simulation of severe shot peening (SSP) aimed at generating nanocrystallized surface layer, Procedia Engineering, 10 (2011), 2923-2930, doi:10.1016/j.proeng.2011.04.485

${ }^{32}$ D. Sun, J. A. Wharton, R. J. K. Wood, Micro-abrasion mechanisms of cast CoCrMo in simulated body fluids, Wear, 26 (2009), 1845-1855, doi:10.1016/j.wear.2009.03.005

${ }^{33}$ S. Bagherifard, M. Guagliano, Fatigue behavior of a low-alloy steel with nanostructured surface obtained by severe shot peening, Engineering Fracture Mechanics, 81 (2012), 56-68, doi:10.1016/ j.engfracmech.2011.06.011

${ }^{34}$ K. Dai, L. Shaw, Comparison between shot peening and surface nanocrystallization and hardening processes, Materials Science and Engineering A, 463 (2007), 46-53, doi:10.1016/j.msea.2006.07.159

${ }^{35}$ G. Liu, J. Lu, K. Lu, Surface nanocrystallization of $316 \mathrm{~L}$ stainless steel induced by ultrasonic shot peening, Materials Science and Engineering A, 286 (2000), 91-95, doi:10.1016/S0921-5093(00) 00686-9

${ }^{36}$ M. A. Terres, N. Laalai, H. Sidhom, Effect of nitriding and shotpeening on the fatigue behavior of $42 \mathrm{CrMo} 4$ steel: Experimental analysis and predictive approach, Materials \& Design, 35 (2012), 741-748, doi:10.1016/j.matdes.2011.09.055

${ }^{37}$ K. Farokhzadeh, J. Qian, A. Edrisy, Effect of SPD surface layer on plasma nitriding of Ti-6Al-4V alloy, Materials Science and Engineering A, 589 (2014), 199-208, doi:10.1016/j.msea.2013.09.077

${ }^{38}$ G. Li, J. Chen, D. Guan, Friction and wear behaviors of nanocrystalline surface layer of medium carbon steel, Tribology International, 43 (2010), 2216-2221, doi:10.1016/j.triboint.2010.07.004 